\title{
Cell Maintenance
}

National Cancer Institute

\section{Source}

National Cancer Institute. Cell Maintenance. NCI Thesaurus. Code C20504.

Processes that promote, sustain, and preserve cell viability. ( $\mathrm{NCl})$ 